\title{
HUMOROUS INTERPRETATIONS OF ABBREVIATIONS AS A SOCIO-CULTURAL PHENOMENON
}

\author{
Piret Voolaid
}

\begin{abstract}
The article discusses the nature of abbreviation jokes, the possible formulation principles, relations to humour and slang and the way their interpretation depends on the socio-cultural context. The abbreviated riddle corpus, (ca 3,000 texts of about 330 types) stored in the Folklore Archives of the Estonian Literary Museum, constitutes the source material for the study. The material has been systematised and presented in the database Eesti lühendmõistatused or Estonian Abbreviation Riddles (Voolaid 2004). The database provides a fine overview of alternative folkloric interpretations of abbreviations and acronyms in different periods and allows us to diachronically observe and describe the transformation of the genre in the socio-cultural context.

The article introduces the possible ways of systematisation and formulation principles of the alternative interpretations of Estonian abbreviations (abbreviation parodies) bordering folklore and language. Folklorists have approached the phenomenon as a subgenre of riddles: the question part consists of a conventional abbreviation, whereas the explanation provided in the answer part is radically different from the conventional one; it is witty and humorous, often with a political or sexual undertone. A single abbreviation may produce several alternative interpretations, including the conventional and the folkloric explanation. Alternative (often witty) interpretation of abbreviations can be considered an important source of the slang lexicon of group languages (e.g., exclusive subcultures, professional parlance) or secret language. ${ }^{1}$
\end{abstract}

Key words: abbreviations, abbreviation parodies, abbreviation riddles, acronyms, folk humour, group lore, quasi-acronyms, slang

Folklore texts are no longer the research domain of folklorists only: interdisciplinary approach often enriches the study of the material. Folklore has entered the research focus of literary theorists, historians, sociologists, psychologists, and since language is the foundation building block of folklore, these texts have also been the research focus of linguists. The boundary between folklore and language is less clearly defined in some folklore genres (e.g., idiomatic expressions, phraseologisms, phrases) than it is in others. Among such phenomena with blurred boundaries are various riddles, which have so far been neglected in Estonian linguistic and humour research. 
Since the second half of the 1990s, Estonian folklorists have compiled a number of digitised text corpora: genre-specific databases which are easily accessible online. Newer riddle material has been gathered in several genretypological databases of similar structure, constructed in recent years (see Voolaid 2006).

Characteristic features of the riddle are dialogic play (see Hasan-Rokem \& Shulman 1996: 3) and the (obligatory) question-answer form. The latter determines the subgenre of riddles, the most important ones are:

- Traditional riddles - the question part is a description of an object, e.g., Üks hani, neli nina? Padi. 'Q: One goose, four noses? A: A pillow.'

- Conundrums - direct 'wh'-questions, e.g., Kumb on raskem, kas kilogramm rauda või kilogramm vatti? Mõlemad on üherasked. 'Q: Which of these weighs more - a kilogram of iron or a kilogram of cotton? A: Both are of the same weight.'

- Compound word games - mostly use the initial formula What? or Which one? expecting, instead of an adjective, a compound noun as an answer, e.g., Missugused jalad ei kõnni? Lauajalad. 'Q: Which legs do not walk? A: Table legs.'

- Droodles - mostly consist of a visual image serving as the question and the description of the image serving as the answer, e.g., Mis on pildil? Neli elevanti nuusutavad apelsini. 'Q: What is this? $\square \stackrel{5}{\square} \square$ A: Four elephants sniffing an orange.' (For more on the typology of Estonian riddles see Voolaid 2005: 11-20). ${ }^{2}$

Abbreviations or acronyms are used so that language users are able to write or utter words and syllables faster. According to the researcher of Estonian abbreviations Martin Ollisaar, who has authored the book of Estonian abbreviations (Lühendiraamat 2006), abbreviation formation in the Estonian language results in:

1) Estonian and loan abbreviations (according to their origin);

2) Uppercase, lowercase and mixed case abbreviations (according to the letter case);

3) General or common abbreviations and textual abbreviations made up for one publication (according to their popularity);

4) Abbreviations with and without periods (according to punctuation) (Ollisaar 2006: 6-12). 
Ollisaar's practical book contains more than 11,000 more or less popular Estonian abbreviations and acronyms, complete with interpretations. Similar commonly known and widely spread abbreviations are stored and held in the Estonian Folklore Archives, although in this case the material is completely different. The aim of these abbreviations is not to spare room in written or oral texts; instead, the genre of these abbreviations shares similarities with riddles.

If we consider the structure of the riddle (question and answer), the question part of the abbreviation riddle is composed of a well-known abbreviation, mostly an acronym (e.g., what does FBI mean?). An alternative reply to the conventional interpretation Federal Bureau of Investigation is quite different, witty and humorous, often with a political or sexual undertone (e.g., Female Body Inspector). One and the same acronym or abbreviation may stand for several alternative interpretations - both the conventional or normative and the folkloric or alternative. Folklorists have come to call such abbreviations abbreviation riddles, although their popular character is also conveyed by terms abbreviation parodies, humorous abbreviations, alternative interpretations of abbreviations or quasi abbreviations.

The aim of the article is to give an overview, on the basis of the database of Estonian Abbreviation Riddles as a genre-specific corpus, of the alternative or folkloric interpretations of abbreviations, the formulation principles, relations to popular humour and slang and the surrounding socio-cultural context.

\section{ARCHIVE MATERIALS UNDER CONSIDERATION}

The earliest of the approximately 3,000 abbreviation riddles recorded and held in the Estonian Folklore Archives date back to 1938 when three folkloric explanations of the acronym ETK were written down. The normative meaning Eesti Tarvitajateühisuste Keskühisus ('Central Union of Estonian Consumers' Unions', 1917-1941, then renamed ETKVL) has been variously adapted: elab tarvitaja kasust 'lives off the consumer', elab teiste kulul 'lives at others' expense' and Eesti töörahva kurnaja 'exploiter of Estonian labourers'.

The main bulk of alternative abbreviation interpretations, collected before the mid-1990s, is folklore about the totalitarian Soviet regime, with a characteristically strong political flavour. Folklore of that era constituted mainly of ridiculing social taboos (the forbidden political, erotic, mundane). Like all antiregime folk humour, ridiculing abbreviation explanations was resolutely ignored. Consequently, collecting and storing such material in the archives was 
out of the question. Some of this folklore has fortunately reached us owing to unsanctioned collectors.

The majority of the folklore of the Soviet period, including abbreviation riddles $(2,200$ of the total of 3,000 texts) was added to the archives as late as in 1992, during the major collection of school lore in Estonia. One reason for such a late addition was censorship. 1992 was the last moment to collect material characteristic of the Soviet period and its society of limited freedom of speech. In 2007, the Estonian Literary Museum and the University of Tartu co-operated in organising another national school lore collection, and during this collection the Estonian Folklore Archives also received some (but few) abbreviation riddles. The article will proceed to comparing material obtained in the course of these two waves of collection.

\section{THEORETICAL BASES - TYPES OF ABBREVIATION RIDDLES, THEIR FORMATION FORMULAE AND RELATIONS WITH HUMOUR AND SLANG}

\section{Classification and formation formulae}

Linguists (e.g., Cannon 1989; Fandrych 2008) have studied abbreviations and acronyms from the morphological aspect. Russian folklorist and humour researcher Aleksandra Arkhipova (2008: 413-446) considers folk contractions a phenomenon of 'new folklore' and linguistic play, and has described these with the terms normative and alternative interpretation. Arkhipova called alternative interpretation of abbreviations 'de-abbreviation' and also provided taxonomy of 'de-abbreviation' that I am going to apply to categorise Estonian material.

1. Popular uppercase abbreviations or acronyms with an alternative explanation. The main bulk of Estonian abbreviation riddles are acronyms made up of initial letters or names written in the uppercase. The initial letters of several words form an acronym that is pronounced like a word (e.g., SAS - Scandinavian Airlines System and the ironic intention - Sex And Satisfaction).

2. There is no normative abbreviation, only the abbreviation with the folkloric explanation emerges. This riddle type is based on the common knowledge that certain kinds of organisations, for example news agencies, are usually referred to by acronyms of their names: $B B C, C N N$, Russian agencies $H T B, T A C C$, Estonian agency ETA, and so on. This habit of shortening news agency names has prompted the rise of Estonian abbreviations for "grapevine" ('heard it through the grapevine') agencies, which tell and spread 
rumours, referred to both in oral speech as well as in the media: NSR-naised saunas rääkisid - 'heard it from women in the sauna' or KNR - keegi naine rääkis 'heard from some woman'. These Estonian riddles may have been prompted by a similar Russian abbreviation ОБГ - одна баба говорила 'a woman told'. Another source for such abbreviations is a spontaneously created phrase that is turned into an acronym.

3. There are noticeably fewer abbreviation riddles in which an existing word or phrase is turned into an abbreviation through later interpretation, known as backronyms. For example, in an episode of The Simpsons, Homer defines GRUNGE as Guitar Rock Utilising Nihilist Grunge Energy, in Estonian material $K O O L$, 'school' in the normative sense, interpreted as standing for kohustuslik orjanduslik orjade liit 'compulsory union of slaving slaves'; UUTMINE 'innovation, perestroika' = uus universaalne töörahva mõnitamine ilma nähtava eesmärgita 'new universal mocking of workers for no obvious purpose'. The Sompa district in the town of Kohtla-Järve has been deciphered as Самое опасное место после Америки 'the second most dangerous place after America'.

4. Abbreviations as a combination of blending and splinters, made up of the first syllables of suitable words or chosen letters. In the Estonian socio-political setting it is important to remember that abbreviations made up of the first parts of lexical units were a Soviet Russian invention. (Many sources attribute this Russian abbreviation practice to the early 20th-century communists, whereas the first "abbreviation boom" took place after the 1917 revolution, see Stakheeva 2008: 9). This method of abbreviation formation was the basis of the whole Soviet "Glavbumsbyt" school of abbreviation tradition (on Russian Soviet vocabulary, incl. abbreviations see Mokienko \& Nikitina (1998)), and it has or had no counterpart in Estonian abbreviation practices. Thus, this abbreviation type has numerous examples in the Russian language, while in Estonian the type is not popular. One of the few representatives is Jo-Te jookse terviseks 'run for health', folkloric alternative joo terviseks 'drink for health'.

A generalisation of the types of abbreviations presented here reveals that the genre includes so-called quasi-acronyms that 1) redefine common uppercase abbreviations, or 2) define or decipher single words or syllabic abbreviations as acronyms, or 3) are formed of spontaneously constructed phrases that could also be presented as an entity of the type the name of which is commonly used in abbreviated form (e.g., news agencies). 


\section{Humour theoretical aspects}

Quasi-acronyms generally have a content relation to their source (e.g., the names or words behind common acronyms). The relation between a quasiacronym and its source is usually comical $\sim$ ridiculing $\sim$ parodying, and could represent any of the main humour topics - political, ethnic, obscene (sexual or scatological) humour.

The affinity of alternative interpretations to comicality is realised through the incongruity theory of humour. All comic acts are based on imagining an idea or situation in two internally congruent but commonly incongruent reference frames (Krikmann 2004a: 10). Consequently, the normative and the alternative interpretation are as if two semantic planes which entail the comical and the collision of which results in a joke. An abbreviation constitutes both the shared portion and source of the two planes; the user, knowing the abbreviation's general and conventional (or normative) meaning, plays with this knowledge and presents his or her own witty interpretation. Humour researcher Victor Raskin has termed these semantic planes (or semantic fields) scripts. According to his semantic theory of humour, a text can be considered funny if it fulfils these two conditions: 1) the text either fully or partially overlaps two different scripts and 2) these two scripts are in some way contrary to one other and evoke a surprise. A text is funny if, and only if, the text is compatible (fully or in part) with two distinct scripts, and the two distinct scripts are in some way opposites (Raskin 1985: 99). Clashes between two incompatible scripts or associative semantic fields are also the prerequisite of any kind of descriptive speech (incl. metaphor and metonymy). Another subgenre of incompatible codes, besides descriptive speech, is jokes and in abbreviation riddles the clash between semantic fields is strong enough to cause comic affect together with a surprise effect. In the case of abbreviations (and other subgenres of riddles) a joke is created if the text is difficult to solve due to its special informationcontaining structure, the solution needs to be reached through multi-stage interpretation, and if various technical principles predetermine the alternative (i.e. wrong) interpretation.

\section{Quasi-abbreviations as part of in-group slang}

The functions of forming parodying abbreviations coincide to an extent with the main purposes of slang - the intention to hide information from bystanders; linguistic economising (shortness); affect (emphasised expression of one's attitude); attempts at humour and novelty; distinguishing oneself from others, emphasising one's nature; undermining authorities and norms (Tender 2003: 17). Various slang studies (e.g., Tender 1994: 352) have noted that abbrevia- 
tions, used for language economy and humour, are one of the most important sources of slang vocabulary. As an in-group language, abbreviation interpretations have a key role in closed subculture communication (e.g., in correctional institutions or the army) or in computer terminology or jargon, which unfortunately has not been recorded in the Estonian Folklore Archives. Humorous acronymic interpretation of computer terminology has been thoroughly studied by the Italian cognitivists, Oliviero Stock and Carlo Strapparava (2003: 297-314), who have created a computer acronym re-analyser.

Rait Maruste, an Estonian judge in the European Court of Human Rights, has studied the tattoos, gestures and slang of Estonian criminal subcultures. Quite interesting is the large number of letter symbols in the tattoos (or scar tattoos) of girls at the Kaagvere correctional school in the 1980s. These, mostly Estonian letter symbols, which essentially are not yet symbols of the criminal culture are often inspired by the lyrics of popular songs and convey specific meanings and naive-romantic aspirations: for example, AAS - austan ainult sind / armastan ainult sind 'only respect you / only love you', IMMSTMSH iga mu mõte sulle teeb mu südamele haiget 'every thought I have makes my heart hurt' (Maruste 1988: 20-26). In his study, Maruste has presented a wide array of Russian letter symbols and figures from all over the Soviet Union; all these symbols have been copied from the tattoos of members of a relatively exclusive social subculture and impart information about power and subordination relationships and often about hierarchical levels.

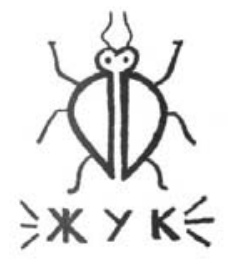

Желаю удачной кражи. (Татуируют осужденным, которые воруют, достают для более привилегированной части осужденных.)

'Wish you successful theft. (The letters are tattooed on the convicts who steal for the more privileged inmates.') (Maruste 1988: 67)

If we consider an acronym with an alternative interpretation part of an ingroup language, then its origin, no doubt, roots in the need to conceal information. Considering the strictness of Soviet censorship and restrictions on publishing, being fluent in the alternative interpretations of Socialist abbreviations certainly indicated that one was part of a lore in-group. Not knowing the abbreviations makes it impossible for a person to understand the message and the underlying humour. 


\section{RESPONSE TO SOCIO-CULTURAL PRESSURE - FROM THE SOVIET TIMES TO TODAY}

\section{Soviet abbreviation legacy}

The following table lists the most popular uppercase abbreviations in the Estonian material by frequency as well as their most popular alternative interpretations, with the number of alternative recordings.

Table 1. The most popular uppercase abbreviations: normative and alternative interpretations, with the number of alternative records

\begin{tabular}{|c|c|c|c|}
\hline $\begin{array}{l}\text { Uppercase } \\
\text { abbreviation }\end{array}$ & Phrase & Most popular interpretation & $\begin{array}{l}\text { Number } \\
\text { of records }\end{array}$ \\
\hline \multicolumn{4}{|l|}{ Type 1} \\
\hline$\overline{C C C P}$ & $\begin{array}{l}\text { Союз Советских Conиалистических } \\
\text { Pеспублик 'Union of Soviet Socialist } \\
\text { Republics' }\end{array}$ & $\begin{array}{l}\text { Siberi sead situvad reas 'Siberian swine } \\
\text { shitting in rows' }\end{array}$ & 470 \\
\hline ETKVL & $\begin{array}{l}\text { Eesti Tarbijate Kooperatiivide } \\
\text { Vabariiklik Liit 'National Union of } \\
\text { Estonian Consumers' Unions' }\end{array}$ & $\begin{array}{l}\text { ela teiste kulul väga laialt 'live very } \\
\text { well at the expense of others' }\end{array}$ & 351 \\
\hline ENSV & $\begin{array}{l}\text { Eesti Nõukogude Sotsialistlik Vabariik } \\
\text { 'Estonian Soviet Socialist Republic' }\end{array}$ & $\begin{array}{l}\text { Eesti naiste sukavabrik 'Estonian } \\
\text { women's stocking factory'; enne nälg, } \\
\text { siis viletsus 'first hunger, then poverty' }\end{array}$ & 300 \\
\hline NLKP & $\begin{array}{l}\text { Noukogude Liidu Kommunistlik Partei } \\
\text { 'Communist Party of the Soviet Union' }\end{array}$ & $\begin{array}{l}\text { näljase Lenini kondine perse 'the bony } \\
\text { ass of hungry Lenin' }\end{array}$ & 127 \\
\hline$N S V L$ & $\begin{array}{l}\text { Nónkogude Sotsialistlike Vabariikide } \\
\text { Liit 'Union of Soviet Socialist } \\
\text { Republics' }\end{array}$ & $\begin{array}{l}\text { näljased silmad vaatavad läande } \\
\text { 'hungry eyes watching towards the } \\
\text { West' }\end{array}$ & 114 \\
\hline EPA & $\begin{array}{l}\text { Eesti } \quad \text { Pôllumajandusakadeemia } \\
\text { 'Estonian Agricultural Academy' }\end{array}$ & $\begin{array}{l}\text { elu parimad aastad 'the best years in } \\
\text { life' }\end{array}$ & 105 \\
\hline KEK & $\begin{array}{l}\text { kolhooside ehituskontor 'building } \\
\text { office of collective } \begin{array}{r}\text { farms', } \\
\text { kommunaalettevòtete } \\
\text { "enterprise ombinaat } \\
\text { establishments' of }\end{array} \\
\end{array}$ & $\begin{array}{l}\text { kerge elu kõigile 'easy life for } \\
\text { everybody' }\end{array}$ & 93 \\
\hline$E \tilde{O M}$ & $\begin{array}{l}\text { Eesti Opilasmalev 'Estonian Students' } \\
\text { Work Camp' }\end{array}$ & $\begin{array}{l}\text { ema õmblusmasin 'mother's sewing } \\
\text { machine' }\end{array}$ & 74 \\
\hline$T P I$ & $\begin{array}{l}\text { Tallinna Polütehniline Instituut 'Tallinn } \\
\text { Polytechnical Institute' }\end{array}$ & $\begin{array}{l}\text { tudengite piinamise instituut 'institute } \\
\text { for torturing students' }\end{array}$ & 71 \\
\hline$U S A$ & United States of America & uus sigade armee 'new army of swine' & 65 \\
\hline $\begin{array}{l}\text { ESRA (union } \\
\text { taxi } \\
\text { connpany) }\end{array}$ & $\begin{array}{l}\text { eriti suur rahaahmus 'extra greed for } \\
\text { money' }\end{array}$ & $\begin{array}{l}\text { Eesti sakste ja retsidivistide ametkond } \\
\text { 'Estonian organisation of bosses and } \\
\text { recidivists' }\end{array}$ & 62 \\
\hline$T P L$ & $\begin{array}{l}\text { töö- ja puhkelaager 'voluntary work } \\
\text { and vacation camp' }\end{array}$ & $\begin{array}{l}\text { tööpõlgurite laager 'canp for work- } \\
\text { haters' }\end{array}$ & 43 \\
\hline$E K P$ & $\begin{array}{l}\text { Eesti Kommunistlik Partei 'Estonian } \\
\text { Communist Party' }\end{array}$ & $\begin{array}{l}\text { eriti kõva pidu 'super party'; eestlane } \\
\text { kardab punast 'Estonians are afraid of } \\
\text { red' }\end{array}$ & 42 \\
\hline$T A C C$ & $\begin{array}{l}\text { Tелеграфное Агениство Советского } \\
\text { Союза 'Telegraphic Agency of the } \\
\text { Soviet Union' }\end{array}$ & $\begin{array}{l}\text { targad ajavad sitta suhu 'wise people } \\
\text { eating shit'; targad ajavad suust sitta } \\
\text { 'wise people talk bullshit' }\end{array}$ & 41 \\
\hline$S R \ddot{U}$ & $\begin{array}{lcr}\begin{array}{l}\text { Söltumatute } \\
\text { 'Commonwealth } \\
\text { Stikide } \\
\text { of }\end{array} & \begin{array}{r}\text { Ühendus } \\
\text { Independent }\end{array} \\
\text { States' } & & \\
\end{array}$ & $\begin{array}{l}\text { sabata rebase ülikond 'suit of a tail-less } \\
\text { fox' }\end{array}$ & 36 \\
\hline
\end{tabular}




\begin{tabular}{|c|c|c|c|}
\hline$\ddot{U} R O$ & $\begin{array}{l}\text { Ühinenud Rahvaste Organisatsioon } \\
\text { 'United Nations Organization' }\end{array}$ & $\begin{array}{l}\text { ïpris raske olukord 'fairly difficult } \\
\text { situation' }\end{array}$ & 35 \\
\hline ETV & Eesti Televisioon 'Estonian Television' & $\begin{array}{l}\text { Eesti tolad, vaadake! 'Watch, Estonian } \\
\text { fools!' }\end{array}$ & 29 \\
\hline$T R \ddot{U}$ & $\begin{array}{l}\text { Tartu Riiklik Ülikool 'Tartu National } \\
\text { University' }\end{array}$ & $\begin{array}{l}\text { tütarlaste riiklik ïlalpidamine 'state } \\
\text { maintenance of girls' }\end{array}$ & 26 \\
\hline ELO & $\begin{array}{l}\text { Eesti Laste Organisatsioon } \\
\text { 'Organisation for Estonian Children' }\end{array}$ & $\begin{array}{l}\text { Eesti lollide organisatsioon 'Estonian } \\
\text { organisation for the stupid' }\end{array}$ & 22 \\
\hline$K \Pi C C$ & 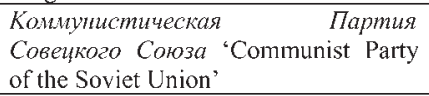 & $\begin{array}{l}\text { kovva pidu sauna ja seksiga 'super party } \\
\text { with sauna and sex' }\end{array}$ & 22 \\
\hline$E V$ & Eesti Vabariik 'Republic of Estonia' & elagu venelased 'long live Russians' & 21 \\
\hline$L P$ & Lugupeetud 'honoured' & $\begin{array}{l}\text { laku perset / panni 'lick my ass / } \\
\text { saucepan' }\end{array}$ & 20 \\
\hline VTK & $\begin{array}{l}\text { valmis töoks ja NSV Liidu kaitseks } \\
\text { 'ready for work and protection of the } \\
\text { USSR' }\end{array}$ & $\begin{array}{l}\text { viruta teisele kaikaga 'hit someone with } \\
\text { a stick' }\end{array}$ & 19 \\
\hline$N S V^{\prime}$ & $\begin{array}{l}\text { Nöukogude Sotsialistlik } \\
\text { 'Soviet Socialist Republic' }\end{array}$ & $\begin{array}{l}\text { naiste sukavabrik 'women's stocking } \\
\text { factory' }\end{array}$ & 17 \\
\hline RTV & $\begin{array}{l}\text { Reklaamitelevisioon 'Advertisement } \\
\text { television' }\end{array}$ & $\begin{array}{l}\text { rotid toodavad venelasi 'rats produce } \\
\text { Russians' }\end{array}$ & 17 \\
\hline ETA & $\begin{array}{l}\text { Eesti Teadete Agentuur 'Estonian News } \\
\text { Agency' }\end{array}$ & $\begin{array}{l}\text { Eesti tarkade asutus 'Estonian } \\
\text { institution for the wise' }\end{array}$ & 16 \\
\hline MEK & $\begin{array}{l}\text { Majaehituskombinaat 'House-building } \\
\text { Enterprise' }\end{array}$ & $\begin{array}{l}\text { meie ehitame kehvasti 'we build } \\
\text { shabbily' }\end{array}$ & 16 \\
\hline ERSP & $\begin{array}{l}\text { Eesti Rahvusliku Söltumatuse Partei } \\
\text { 'Party for Estonian National } \\
\text { Independence' }\end{array}$ & $\begin{array}{l}\text { Edaspidi rohkem sõmnikut pöllule 'in } \\
\text { the future, more manure to fields'; } \\
\text { Eesti riiklik spermapank 'Estonian } \\
\text { national sperm bank' }\end{array}$ & 15 \\
\hline SOS & $\begin{array}{l}\text { save our souls/ship 'päästke meie } \\
\text { hinged päästke meie laev' }\end{array}$ & seisukord on sitt 'situation is shitty' & 15 \\
\hline$K G B$ & $\begin{array}{l}\text { Konитеm Государственной } \\
\text { Безоnасиости 'Committee of National } \\
\text { Security' }\end{array}$ & $\begin{array}{l}\text { kuritegelik Gorbatšovi } \\
\text { 'Gorbachev's criminal band' }\end{array}$ & 15 \\
\hline$K P$ & $\begin{array}{l}\begin{array}{l}\text { Kommunistlik Partei } \\
\text { party' }\end{array} \\
\text { 'Communist }\end{array}$ & kõva pidu 'super party' & 13 \\
\hline$L K$ & Lehekülg 'page' & lollide koloonia 'colony of the stupid' & 12 \\
\hline NLI & $\begin{array}{l}\text { noor liiklusinspektor 'young traffic } \\
\text { inspector' }\end{array}$ & nelja lapse is a 'father of four children' & 11 \\
\hline$R R$ & Rahvarinne 'National Front' & $\begin{array}{l}\text { räketite rühm } \\
\text { 'group of racketeers'; roohume rinnaga } \\
\text { 'we oppress with our breasts' }\end{array}$ & 11 \\
\hline \multicolumn{4}{|l|}{ Type 3} \\
\hline ARS & (artists' enterprise $A R S$ ) & $\begin{array}{l}\text { anna raha siia 'give me all your } \\
\text { money' }\end{array}$ & 31 \\
\hline$L O L L$ & 'Stupid' & $\begin{array}{l}\text { Leonid! Olen laudas. Leida 'Leonid! I } \\
\text { am in the stable. Leida' }\end{array}$ & 11 \\
\hline UUTMINE & 'Innovation' & $\begin{array}{l}\text { uus universaalne töörahva mönitamine } \\
\text { ilma nähtava eesmärgita 'new universal } \\
\text { mocking of workers for no obvious } \\
\text { purpose' }\end{array}$ & 12 \\
\hline
\end{tabular}

Table 1 indicates that the most common folkloric abbreviations in the Estonian Folklore Archives follow the first formation formula of the above classification: well-known uppercase acronyms are given an alternative interpretation.

The most common political acronyms among abbreviation riddles are, first and foremost, interpretations of the contractions of the names of countries 
and political parties. In the so-called Socialist acronyms (see Krikmann 2004b: 366 ) the top ten of the Soviet state names, such as CCCP, NSVL, ENSV, rank at the highest. There is also a political undercurrent in the witty explanations of Soviet party names NLKP, KICC and EKP (once also a contamination of the latter two, EKPSS, with the explanation eriti kõva pidu sauna ja seksiga 'super party with sauna and sex'). Party names have inspired witty folk interpretations in more recent times as well (e.g., the ERSP - 'Party for Estonian National Independence' established in the late 1980s).

Most alternative abbreviation interpretations are disparaging, having a negative connotation; the only positive among those included in the Table is the folkloric interpretation of the acronym EPA. Many texts of the period aim to express national identity; the distinction of one ethnic group from another group, the opposition of 'Us' and 'Them' is clearly evident. Many alternative interpretations reflect Estonian patriotism: the contents of the texts are sometimes highly hostile and aggressive, instigating fight and rebellion (e.g., ETKVL - Eestlane tagus kaikaga venelasele lagipähe 'The Estonian hit the Russian's head with a club', VTK - viruta teisele kaikaga 'hit the other one with a club')

Witty and humorous alternative abbreviation interpretations are part of the Soviet 'censored humour' and thus characterise a repressive society where people were not allowed to legally express their discontent (Sarv 1995: 107). The leading Estonian folklorist Oskar Loorits has approached the jokes of the occupation period as a form of folk mockery and has shown how times of great tribulations and disasters, such as occupations and wars, prompt the display of the idiosyncrasies of the collective ethnic soul. According to him, an Estonian is not only an "aggressive activist but an utterly reactive character, whose fermentation usually crystallises into raillery" (Loorits 1994: 9). Abbreviation interpretations also show how the (forced) adoption of a foreign culture (e.g., the above-mentioned practice of creating new terms by contraction abbreviation) resulted in a number of unpleasant interpretations (Loorits 1994: 19). This kind of compensatory humour derided or criticised not only political rulers as individuals, but the whole social and political system together with its underlying ideology, rituals and myths. Since such jokes were completely banned in the media, they could only be spread as collective creation and authentic oral folklore. British humour researcher Christie Davies has reasoned that jokes common under the Communist rule were one of the forms that people's political protest took, a substitute for the social psychological depression, expression of cynical adaptation or pessimistic resignation (Davies 2007: 291305). In any case, alternative interpretation of abbreviations can be treated in Soviet discourse as the secret code of a people distanced from power expressing their political attitudes towards the governing regime. 
Linguists have considered specialised languages - argot, jargon or slang - a creation of some sort, one that expresses the creator's freedom, spirit of protest and sense of humour (Loog 1991: 8). The creativity of abbreviations as such becomes evident in the vast number of interpretation variants or improvisational texts of some acronyms. The most remarkable among these is the acronym $C C C P$ (see Table 1 ) with its highly varied interpretations. Nearly one third of all the alternative interpretations of the acronym CCCP/SSSR 'USSR' are based upon Joseph Stalin (General Secretary of the Communist Party of the Soviet Union in 1928-1953). Table 2 presents a selection of various alternative interpretations of a single acronym.

Table 2. Alternative interpretations of acronym CCCP/SSSR built upon Joseph Stalin.

\begin{tabular}{|c|c|}
\hline No. & Alternative interpretation \\
\hline 1. & Stalin söitis seaga ratsa 'Stalin rode on a pig' \\
\hline 2. & Stalin söitis Siberi rongis 'Stalin travelled on the train to Siberia' \\
\hline 3. & Stalin sõitis seaga Riiga 'Stalin rode on a pig to Riga' \\
\hline 4. & Stalin sittus sirged read 'Stalin shat straight rows' \\
\hline 5. & Stalin sittus, saba rõngas 'Stalin shat, tail twisted' \\
\hline 6. & Stalin sôtis seaga Rootsi 'Stalin took the pig to Sweden' \\
\hline 7. & saamatul Stalinil seitse raha "inadequate Stalin has seven bills of money" \\
\hline 8. & Suur Stalin, situ ruttu! 'Stalin the Great, shit fast!' \\
\hline 9. & Stalin situs seitse rida 'Stalin shat seven rows' \\
\hline 10. & seltsimees Stalin situb ruttu 'Comrade Stalin shits fast' \\
\hline 11. & Stalin soitis sigadega rongis 'Stalin travelled with pigs on the train' \\
\hline 12. & Stalin sõidab Stahhanovi rongis 'Stalin travels on train to Stakhanov' \\
\hline 13. & Stalin sittus sirge rivi 'Stalin shat a straight row' \\
\hline 14. & siga sittus Stalini rabarberiaias 'pig shat in Stalin's rhubarb garden' \\
\hline 15. & Stalin sittus suure rubla 'Stalin shat a large rouble' \\
\hline 16. & suur Stalin sõi rongis 'Stalin the Great ate in the train' \\
\hline 17. & Stalin suri, saba röngas 'Stalin died, tail twisted' \\
\hline 18. & Stalini sead sittusid reas 'Stalin's pigs shat in a row' \\
\hline 19. & Stalin sikutab surnud rotti 'Stalin is pulling a dead rat' \\
\hline 20. & Stalin sonis Siberi rongis 'Stalin was delusional on a train to Siberia' \\
\hline 21. & Stalin sööb sigadega reas 'Stalin eats with pigs in the row' \\
\hline 22. & $\begin{array}{l}\text { Catepm } \text { Cmanuнa Cnacem Pосcию 'Stalini surm päästab Venemaa' 'Stalin's } \\
\text { death salvages Russia' }\end{array}$ \\
\hline
\end{tabular}

Here it is important to note that humour, targeted at Soviet authorities, is a subcategory of the entire anti-regime political humour. The list of the acronyms (presented in Table 1) indicates that next to Stalin the main characters featured in acronym interpretations that were also General Secretaries of the Communist Party of the Soviet Union, are Vladimir Lenin (General Secretary in 1917-1924) and Mikhail Gorbachev (General Secretary in 1985-1991).

Quite characteristically of the social and political situation of the Soviet period, many phrases that inspired the emergence of the alternative interpretations of acronyms, including the most popular $C C C P$ (but also $K \Pi C C$ ) have 
been Russian; interpretations are either completely in Estonian or Russian, or combine both. The conveying of the same folklore text in more than one language is also known as code-mixing or code-switching. Linguists have termed the switching of languages from one sentence to another as code-switching (Sridhar \& Sridhar 1980: 408-409) and intra-sentential switching of languages as code-mixing (Appel \& Muysken 1992: 117-118). By analogy one may argue that an abbreviation which was originally in foreign language (in the Soviet period in Russian) and which answer was also completely in the foreign language (also in Russian) was essentially code-switching. The application of different languages (both Russian and Estonian) in the context of a single acronym and its interpretations can be termed as code-mixing; this is highly common in anecdotes and other types of jokes. Such switching and mixing Estonian and Russian language codes points to the predominance of Russian language in official matters and common interaction in the Soviet republics (although the reputation of Russian as the language of the political authorities at the time was quite low among the Estonian ethnic population).

On the other hand, Russian abbreviations confirm that this folkloric phenomenon was (and still is) highly popular in the Russian language; it implies the conflict between the Soviet regime and the population, and humour of this type reached the Soviet Republic of Estonia (and other Soviet republics) from Russia.

The popularity of the acronym $C C C P$ can be accounted for by several factors, the most important of which is probably the harmony which is of vital importance in folkloric poetics. The initial triple s-sound of the abbreviation forms an intense alliteration. The acronym itself offers a fine opportunity to employ the name of Stalin. The gory time of Stalin's terror which entailed mass deportations, genocide, arrests, have been associated with the acronym of the country under his leadership. The lexica of interpretations - comrade, ride the train to Siberia - expresses evaluation, and the use of scatological vocabulary expresses the opinion of the general population.

A rather important aspect in terms of quasi-abbreviation is how it sounds (incl. pronouncing the acronym by separate letters or as a word). According to Arkhipova, the third type of abbreviation practice, in Russian and typical of the Soviet period, was to some extent also adopted in Estonian, especially those sharing common foreign roots with the Russian original abbreviation (colloquial partbüroo 'partbureau' or 'party bureau', perbüroo 'fambureau' or 'family bureau', sanepidjaam 'sanepidstation' or 'sanitary epidemiological station', purely Russian derivative glavlit, 'Glavlit' or 'Main Administration for the Protection of State Secrets in the Press under the USSR Council of Ministers', etc.). Association with original Russian acronyms may have formed already 
phonologically (without parodying or alternative interpretation) with some Estonian reduplicate or other humorous constructs главвторсырье - Министерство легкой промышленности 'kergetööstuse ministeerium' ('Ministry of Light Industry'); бумснабсбыт - База издательства "Уральский рабочий” 'väljaande “Уральский рабочий” toimetusbaas' ('Editorial centre for the publication Ural'skii rabochii'). The length of some of these abbreviations or the sometimes ridiculous bureaucratic explanations made these jokes highly amusing (e.g., during the civil war there was reportedly an organisation in Russia which name was abbreviated as Эквалап, or Экономическая комиссия для снабжения Красной армии валенкими и лаптями Economic Committee for Supplying the Red Army with Felt Boots and Birch-Bark Shoes').

More recent acronyms in Estonian and in English include many that make an Estonian-speaker smirk: for instance, ALLEA (All European Academies) is pronounced similarly to alleaa!, an interjection in Estonian folksong refrains, UTKK (Underi ja Tuglase Kirjanduskeskus 'Under and Tuglas Literature Centre of the Estonian Academy of Sciences') is pronounced [utekaka], while the word utekaka in Estonian means 'ewe pooh', and so on. To acronyms may also be added alliterative extensions (SOS-signaal - soss-signaal 'SOS signal = duffer signal') or rhymes (Kompsud kotti ja emtejotti (MTJ-i)! - MTJ on masinatraktorijaam 'Pack your things and to MTJ - MTJ is machine and tractor station').

One type of acronyms is referred to by the same name but are, in essence, similar to acrostics, i.e. the acronym is formed of initial letters that would give a word or name symbolising, describing or promoting some denotative: BERTA or B+Eesti Rahvakalendri Tähtpäevade Andmebaas 'BERTA: Database of Estonian Folk Calendar Holidays', ERASMUS - European Region Action Scheme for the Mobility of University Students. An acronym is often used as a word or name though many users are not even aware of the full form of the name.

\section{Contemporary abbreviation riddles}

Obviously, the majority of Soviet abbreviations disappeared from the general use after Estonia regained independence in 1991. With the arrival of democracy, the degree of politicisation of jokes greatly diminished since criticism towards and discontent with politics and the authorities could now be expressed publicly in the media. In the $1990 \mathrm{~s}$, during preparations for entering NATO and the European Union, a lot of new terms and (foreign) abbreviations were adopted in the Estonian language, giving rise to a new wave of alternative interpretations. Archival records include two alternative interpretations for NATO from 1996, both giving the abbreviation a nationalistic twist - natsio- 
nalistide amoraalne terroristlik organisatsioon 'amoral terrorist organisation of nationalists' and natsliku antitõotuse organisatsioon 'Nazi anti-pledge organisation'. However, today the creation of new alternative abbreviations follows most often the third formation formula of Arkhipova's system where some message inspires a new abbreviation. For example, a recently emerged popular abbreviation in Estonian is JOKK - juriidiliselt on kõik korrektne 'everything is legally correct'. This abbreviation used to mock the Estonian politicians' habit of making openly corruptive deals and later denying allegations of corruption and claiming that no law was broken. At the same time, the word jokk carries the normative meaning 'over, and that's it, spent', and the word occupies the same semantic field in contemporary Estonian journalistic and comment discourse.

Another characteristic feature of the contemporary abbreviation tradition is the general trend in the Estonian language, according to which earlier Soviet Russian influences were being replaced by those of the Anglo-American cultural space and the English language. Contemporary technological vocabulary is largely borrowed from English and this is also reflected in abbreviation interpretations. In any case, abbreviation riddles are still used for expressing quick social reactions today. A humorous evaluation was, for example, given to the Estonian identity card (ID-kaart), issued since 2002, which the general folk called idioodikaart 'idiot's card' (Tartu Postimees 2009: 3), or another example from the heyday of SMS quick loans in 2008 SMS-laen 'SMS-loan' - saad maksta surmani 'you will be paying it off until you die' (Maaleht 2008: 32). In the summer of 2009 , jokes about the global economic depression started to spread, expressed in abbreviations MASU, TÄPE and PUPU. MASU is formed of the initial letters of the Estonian words majandus 'economic' and surutis 'depression' and the analogous rather vulgar folkloric abbreviation explanations characteristic of the complicated economic situation TÄPE or täitsa perses and PUPU or puhta putsis, both could be translated as 'completely f-d up'. (see http://vabatahtlikunahispaanias.blogspot.com/2009/07/kolm-sopra-masu-tape-japupu.html, accessed on 30 Nov 2009). This indicates how societal processes continue to inspire new minor forms of folklore. To give another example, it has become a common practice to accuse Andrus Ansip, currently Prime Minister of Estonia, in any problem imaginable. His name has been expressed in abbreviation lore with the interpretation annab sipelda 'calls for squirming' (available at http://www.delfi.ee/news/paevauudised/eesti/eesti-annab-valgeveneulikoolile-200-000-krooni.d?id=27232013\&com=1, accessed on 30 Nov 2009).

The scanty material that we received during the 2007 school lore collection campaign nicely illustrates the developmental trends of abbreviation heritage. Naturally, earlier popular terms are not known among contemporary youth. 
Table 3. A selection of abbreviation interpretations recorded during the 2007 school lore collection campaign

\begin{tabular}{|c|c|c|}
\hline $\begin{array}{l}\text { Uppercase } \\
\text { abbreviation }\end{array}$ & Phrase & Interpretation \\
\hline \multicolumn{3}{|l|}{ Type 1} \\
\hline$F B I$ & Federal Bureau of Investigation & female body inspector \\
\hline$U S A$ & United States of America & uskumatult suur armastus 'unbelievably big love' \\
\hline$T I R$ & Transports Internationaux Routiers & teen ise remonti 'I do my own renovations' \\
\hline$B M W$ & Bayerische Motoren Werke AG & Big Money Waste \\
\hline$L P$ & Lugupeetud 'honoured' & lollakas peedike 'stupid little beetroot' \\
\hline m.o.t.t. & mida oligi tarvis tõestada 'Q.E.D.' & $\begin{array}{l}\text { mida Oolup (mata-öps) tahtiski toestada 'what Oolup } \\
\text { (a Math teacher) wanted to be demonstrated' }\end{array}$ \\
\hline Jne & ja nii edasi 'and so on' & Jänes näksis edukust 'rabbit nibbled on success' \\
\hline \multicolumn{3}{|r|}{ 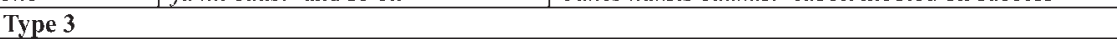 } \\
\hline G.A.Y. & gay & Girly And Youth \\
\hline$J O K K$ & & $\begin{array}{l}\text { juriidiliselt on köik korrektne 'everything is legally } \\
\text { correct' }\end{array}$ \\
\hline \multicolumn{3}{|l|}{ Type 2} \\
\hline$\angle M A O$ & & Laugh My Ass Off \\
\hline$L O L$ & & Laughing Out Loud \\
\hline$O M G$ & & Oh My God \\
\hline SOAD & & Sod Off And Die \\
\hline$V V$ & & väga vaja 'need very much' (väljavalitu 'beloved') \\
\hline
\end{tabular}

The abbreviations that schoolchildren use clearly illustrate the trend that Russian codes are being replaced by English ones. The majority of abbreviations are internationally known, and, as before, re-interpretation is applied to existing acronyms (FBI, USA, TIR, BMW, etc). Yet, compared to earlier times, the contemporary repertoire mostly contains formation formulae in which there is no original normative abbreviation, and the folkloric abbreviation is instead the original (LMAO, LOL, OMG, etc), and has clearly been applied in youth sub-language.

Contemporary Internet humour includes many new abbreviation interpretations, often as separate thematic cycles. Estonian humour websites include a lot of English abbreviation riddles. One of the most popular ones features car brand explanations (1).

(1) AUDI - Automatic Utilisation of Democratic Individuals

BMW - Bubble Machine on Wheels

FIAT - Fabricated Imposter Automobile for Trouble

FORD - Freezing Occasionally Refreshes Dead

HONDA - Hourly Orgasm Needs Dedicated Amortisation

KIA - Killing Instantly Anybody

MAZDA - Masochistic Application of Zipper Drivers Association 
OPEL - Obvious Pollution and Environmental Leak

SAAB - Suddenly Arrive Accident of Bill

(http://publik.delfi.ee/jokes/index.php?sdate=\&category=\&top=\&search= BMW\&no=40, submitted by users 06.11.2000 16:36, Delfi naljaleht, accessed on 30 Nov 2009)

There are series of English witty airline company name interpretations. I will present here a few well-known company names (2), their interpretations based on the one hand on something unpleasant and bothersome that could happen to a regular passenger in the powerful flight system, and on the other hand on the erotic-obscene dimension.

(2) Finnair - Flies Ideally? Nah, Not Airborne In Reality

LOT - Lots Of Trouble

SAS - Service After Sex

Sex And Satisfaction

Such A S***

(http://www.travel-images.com/airline-acronyms.html, accessed on 30 Nov 2009)

\section{ABBREVIATIONS IN ANECDOTE PLOTS - RELATIONS TO OTHER FOLKLORE GENRES, INCL. NARRATIVES}

The Estonian abbreviation repertoire has been imbued with foreign influences and one of the reasons why this might be so is the fact that compared to both the Russian and English languages, the Estonian language has been much less prone to the use of abbreviations. Thus the interpretation of foreign abbreviations could be a kind of rebellion against their overuse. An anecdote featured on the Delfi Naljaleht (the most popular Estonian humour website) seems to support precisely that idea:

(3) I used to work for the KGB, then I crossed over to the CIA. Now I'm working for the FBI and IMF. I drive to work in a blue BMW, sometimes also a red TVR and listen to R.E.M. and AC/DC CDs. At home I watch the BBC and RTL. (http://publik.delfi.ee/jokes/index.php, accessed on 25 Sept 2008)

This last joke is built upon the excessive use of acronyms in a short text and not the humorous interpretation of acronyms. Abbreviations borrowed from English and those in which pronunciation rules follow those in English can 
also cause joking (as a form of protest), especially if it is supported by a phonetic effect: Kirjuta pii-siiga oma sii-vii ja salvesta sii-diile 'Write your CV on a PC and save it on a CD'.

Abbreviations and, first of all, quasi abbreviations have been incorporated into the Estonian anecdote corpus to a large extent. The humorous interpretation of abbreviations forms the basis of the following political anecdote recorded in 1975 about world-famous chess-players.

(4) Telegram from Fischer. When the American player Fischer had beaten our Spassky in chess, he sent to Moscow the telegram "KPSS". When asked what it means, Fischer explained: "Kaputt Petrosian Spassky". The text is followed by the collector's note: told by my grandson, a student. Heard from others. (RKM II 316, 47 (2))

To understand this joke one requires contextual background knowledge about the history of chess. The use of the acronym KPSS here could be related to the 1970 great chess confrontation of the USSR versus Rest of the World, when the Dutch player Bent Larsen and Boris Spassky played in the first round, American Robert James "Bobby" Fischer and Tigran Petrosian the second round (both Spassky and Petrosian were defeated). In 1973, Fischer received the title of World Champion, making the spread of that anecdote in the mid-1970s anticipatory.

Witty deciphering of the KPSS-abbreviation has inspired also other anecdotes (5), even in jokes with one of the most popular Estonian anecdote characters, Juku (6).

(5) Teacher: "Let us review abbreviations. Madis, tell us, please, what does the abbreviation KPSS mean?" Madis: "I think, I mean I have heard that it means 'we'll have a party with sauna and sex'?" (RKM, KP 62, 55 (153))

(6) Juku had to repeat third grade. Teacher, being clever, gave Juku three questions, saying: "If you can answer all the questions, you'll be admitted to the fourth grade." The first question: "What does KP mean?" The second question was "What does EKP mean?" and the third question was "What does KPSS mean?" The answers were: "1. Super party. 2. Extra super party. 3. Extra super party with sauna and sex.” (EFA II 12, 246. 1980/1981)

A similar ruse is employed in the following narrative collected in 1991, inspired by the popular abbreviation riddle ETKVL (although the narrative does seem to be artificially constructed) (7). 
(7) What were ETK and ETKVL? Two life-long farmers are discussing what the difference was between the pre-Soviet ETK and the Soviet ETKVL. They ask a wise man. "The difference is," replies the wise man, "that ETK meant 'lives at the expense of others', while ETKVL means 'lives even better at the expense of others'." (RKM II 442, 706 (14))

The milk-maid Leida Peips rose to fame in the 1970 when she was awarded the merit of a hero of Socialist labour. Thereafter she was very popular in anecdotes. Folk tradition paired Leida Peips with the then social leader Leonid Ilyich Brezhnev and used even the abbreviation riddle form: Mis on LLL? Leonidi lehm Leida 'What's LLL? Leonid's cow Leida'. A very popular anecdote, also based on abbreviations, describes Brezhnev's visit to Leida:

(8) Brezhnev comes to visit Leida Peips. They arrive. Leida is nowhere to be found, but somebody has scratched "LOLL" [Est. 'stupid'] on her door. Brezhnev wants to know what's written there. The interpreter reads: "Leonid! Olen laudas. Leida." 'Leonid! I'm in the cowshed. Leida.' (RKM I 21, 328 (14))

As we can see, this anecdote did not decipher a much-used acronym, but a regular word.

Another true joke tells of the famous Soviet-Estonian actor Lauri Nebel who used to wear a jacket with large letters NLKP on its back. When the Soviet police stopped him and asked for an explanation, he replied that he was simply introducing himself 'Nebel, Lauri, Karli poeg 'Nebel, Lauri, son of Karl' (the abbreviation riddle database entails eight records of this cliché).

Jüri Viikberg's anecdote collection contains this anecdote of Pushkin, which was wide spread in the 1960s:

(9) Pushkin is at a social event and the great poet is asked to give a table speech, the shorter the better. Pushkin stands up and says: Жопа ['ass']. Everyone is baffled and indignant while ladies are hiding their faces, some frown. Pushkin stands up again and explains: Желаю обществу приятного аппетита. ['I wish everyone good appetite']. (Viikberg 1997: 70)

In all the above jokes humour is revealed only after the audience is given the explanation of the abbreviation, which cannot be guessed on the first listening and which evokes surprise. Thus, once again, the use of abbreviations in jokes is on the one hand related to joking, but on the other hand to the in-group language of lore groups - abbreviations tend to confuse people outside the group and/or those who are not familiar with these. 


\section{CONCLUSION}

The study explores the so-called quasi-abbreviations, which in folkloristics are referred to as abbreviation riddles, abbreviation parodies, alternative interpretations of abbreviations, quasi-acronyms. The source material is mainly derived from the digital database Estonian Abbreviation Riddles, the material from the 2007 school lore collection campaign in Estonia and, to lesser extent, abbreviation and acronym material available online and in printed sources. The Estonian abbreviation riddle database is a full-text corpus that follows specific criteria and provides a good cross-section of the folkloric $\sim$ alternative interpretations of abbreviations in different eras and permits diachronic observation and description of genre changes. The aim of this condensed text corpus is to indicate to the abbreviation creation born from witty expression, joking and identity construction on the one hand and the preservation of the material spread in different times and perpetually changing as a socio-cultural archive memory, on the other. Folklorists have approached the phenomenon as a subgenre of riddles: the question part consists of a conventional abbreviation, whereas the explanation provided in the answer part is radically different from the conventional one; it is witty and humorous, often with a political or sexual undertone. Regarding the example of Arkhipova it is possible to speak of the normative or alternative interpretation(s) of the same abbreviation. Estonian abbreviation riddles are formed using four main principles: 1) popular uppercase abbreviations or acronyms are given an alternative explanation; 2) abbreviation riddles in which an existing word or phrase is turned into an abbreviation through later interpretation, 3) abbreviations as a combination of blending initial syllables or selected letters or 4 ) the formation of the folkloric interpretation from the very start.

The abbreviation lore of the Soviet period is mostly based on the first formation method and the second and third types are quite rare. Contemporary abbreviation lore falls under the fourth type and serves mostly as communicative specialised language. The third method, based on blending, is not very typical of the Estonian language and is thus absent in folklore.

Since language and folklore are strongly related to socio-cultural processes, the development of abbreviation riddles is influenced by the general tendencies in culture and society. Abbreviation parodies used to be an established tradition which was spread orally. Part of this tradition - namely, the political Soviet abbreviation repertoire - has disappeared due to social processes. However, its place has been taken by a new tradition, one that has been primarily influenced by the technological progress and the Anglo-American cultural space, 
in which both acronyms and blendings are symbols of the second half of the 20th century.

The folkloric interpretation of abbreviations is closely related to aspiration of humour and humour-theoretical rules and the model of incongruence are applied, or in other words a two-dimensional conceptual plane is created, to create a joke. The joke is born when the basic plane (the normative abbreviation interpretation) is unexpectedly replaced with an alternative plane (interpretation). As a phenomenon of non-institutional spiritual culture, abbreviation interpretations are highly context-related, the humour of these abbreviations is based on poetic devices as harmony (alliteration, end rhyme, etc.)

From the linguistic point of view, alternative interpretations for abbreviations share similarities with slang. The intention to hide information from outsiders; linguistic economising (brevity); affect (emphasised expression of one's attitude); attempts at humour and novelty; differentiating oneself from others, emphasising one's true nature; undermining well-known authorities and norms form the in-group lore of quasi abbreviations. Abbreviation folklore is used in modern technological communication channels as a symbol of group identity. We may agree with Garland Cannon (1989: 108), who says that creativity plays a major role in the formation of some acronyms and [a]cronyms are among the most creative, freewheeling creations in vocabulary today.

\section{NOTES}

1 The article was prepared within the framework of the state programme project SF0030181s08 "Narrative Aspects of Folklore. Power, Personality and Globalization" and grant projects ETF8137 "Cultural processes in the Internet societies. Narratives, values and places" and ETF8149 "Cultural processes in the changing society: Tradition and creativity in post-socialist humour".

2 The technical specifics and structure of the database Estonian Abbreviation Riddles (and of other riddle databases of more recent origin) has been explored in Voolaid 2006. 


\section{REFERENCES}

Appel, René \& Muysken, Pieter 1992. Language contact and bilingualism. London \& New-York \& Melbourne, Auckland: Edward Arnold (a division of Hodder \& Stroughton).

Arkhipova, Aleksandra 2008. VKhOD i KOT kak anekdot: ot iazykovoi igry k "novomu fol'kloru' v 20-e gody XX veka. Tipy dezabbreviatsii - ot abbreviatury k tekstu. In: W. G. Weststeijn (ed.) Delo avangarda. The Case of the Avant-Garde. Pegasus Oost-Europese Studies 8. Amsterdam: Uitgeverij Pegasus, pp. 413-446.

Cannon, Garland 1989. Abbreviations and Acronyms in English Word-Formation. American Speech, Vol. 64, No. 2, pp. 99-127.

Davies, Christie 2007. Humour and Protest: Jokes under Communism. International Review of Social History, Vol. 52, Supplement 15, pp. 291-305.

Fandrych, Ingrid 2008. Submorphemic elements in the formation of acronyms, blends and clippings. Lexis 2: "Lexical Submophemics / La submorphémique lexicale", pp. 105-123. http://screcherche.univ-lyon3.fr/lexis/IMG/pdf/Lexis_2_Fandrych2.pdf, last accessed on 30 Nov 2010.

Krikmann, Arvo 2004a. Koestler, Raskin, Attardo ja teised: lingvistiliste huumoriteooriate uuemaist arenguist. [Koestler, Raskin, Attardo and others: Contemporary Linguistic Theories of Humour]. Reetor 4. Tartu: EKM \& EKFK.

Krikmann, Arvo (ed.) 2004b. Netinalju Stalinist-Internet-anekdoty o Staline - Internet Humour About Stalin. Tartu: EKM \& EKFK.

Loog, Mai 1991. Esimene eesti slängisõnaraamat. [The First Estonian slang Dictionary].Tallinn: Mai Loog.

Loorits, Oskar 1994 [1950]. Okupatsioon rahvapilke kõverpeeglis. [Estonian Humour about Occupation]. Tallinn: Olion.

Maaleht = newspaper "Maaleht", May 8, 2008.

Maruste, Rait 1988. Kuritegelik subkultuur tätoveeringutes, estides, slängis: õppevahend. [Criminal Subculture in Tattoos, Gestures, Slang: Study Aid]. Tartu: Tartu Riiklik Ülikool.

Mokienko, Vakerii \& Nikitina, Tatiana 1998. Tolkovyi slovar" iazyka Sovdepii. St. Petersburg: Sankt-Peterburgskii Gosudarstvennyi Universitet.

Ollisaar, Martin 2006. Lühendiraamat. [Book of Abbreviations]. Tallinn: Kirjastus Valgus.

Raskin, Victor 1985. Semantic Mechanisms of Humor. Dordrecht \& Boston \& Lancaster: D. Reidel Publishing Company.

Sarv, Kadi 1995. "Mina tahan ka Nõukogude Liidus elada!": Poliitiline anekdoot koolipärimuses. ["I Want to Live in the Soviet Union, Too!": Children's Political Anecdotes in School Lore]. Lipitud-lapitud: Tänapäeva folkloorist. [About Contemporary Folklore.] Tartu: EKI \& EKM, pp. 106-160.

Sridhar, Shikaripur N. \& Sridhar, Kamal K. 1980. The syntax and psycholinguistics of bilingual code mixing. Canadian Journal of Psychology, Vol. 34, No. 4, pp. 407416.

Stakheeva, Anastasiia 2008. Slovoproizvodstvo i slovotvorchestvo (na materialakh russkogo iazyka kontsa XXI veka). Avtoreferat dissertatsii na soiskanie uchenoi 
stepeni kandidata filologicheskikh nauk. Rostov-on-Don: Izdatel'stvo Iuzhnogo Nauchnogo tsentra RAN. http://www.znb.rsu.ru/referat/D212-208-09/10-02-01/ 20081230_D212-208-09_10-02-01_StaheevaAV.doc, last accessed on 30 Nov 2009, no longer available.

Stock, Oliviero \& Strapparava, Carlo 2003. HAHAcronym: Humorous agents for humorous acronyms. Humor - International Journal of Humor Research, Vol. 16, No. 3, pp. 297-314.

Tartu Postimees = newspaper "Tartu Postimees", January 13, 2009.

Tender, Tõnu 1994. Eesti släng: olemus ja uurimislugu. [Estonian Slang: its essence and research history]. Keel ja Kirjandus [Language \& Literature], Vols. 5-6, pp. 291-299, 346-355.

Tender, Tõnu 2003. Slängi mõiste ja funktsioonid. [The concept and functions of Slang]. In: U. Ilm \& T. Tender (comp.) Trellide ja luku taga. [Behind Bars and Locks]. Tartu: Atlex, pp. 11-17.

Viikberg, Jüri 1997. Anekdoodiraamat: Naeruga eilsest: Eesti anekdoot 1960-1990. [A Book of Anecdotes: With Laughter from Yesterday: Estonian anecdotes 19601990]. Tallinn: Eesti Keele Instituut.

Voolaid, Piret 2004. Eesti lühendmõistatused. Elektrooniline Interneti-andmebaas. [Estonian Abbreviation Riddles. Electronic Internet Database]. Tartu: Eesti Kirjandusmuuseum. http://www.folklore.ee/Lyhendid, last accessed on $30 \mathrm{Nov}$ 2010.

Voolaid, Piret 2005. Eesti mõistatuste perifeerne aines. Elektroonilised andmebaasid Internetis. [The Periphery of Estonian Riddles: Digital Online Databases]. Master's Thesis. Tartu: Tartu Ülikool. http://dspace.utlib.ee/dspace/bitstream/10062/ 1216/5/voolaid.pdf, last accessed on 30 Nov 2010.

Voolaid, Piret 2006. Mõistatuste perifeeria digitaalsed andmebaasid aastal 2006 . Vahefiniš. [Digital Databases of the Periphery of Riddles in 2006. Interim Finish]. In: M. Kõiva (compiler). Võim ja kultuur 2. Eesti Kultuuriloo ja Folkloristika Keskuse aastaraamat. [Power and Culture 2. Yearbook of the Centre of Cultural History and Folkloristics in Estonia]. Tartu: EKM \& EKFK, pp. 125-160. 